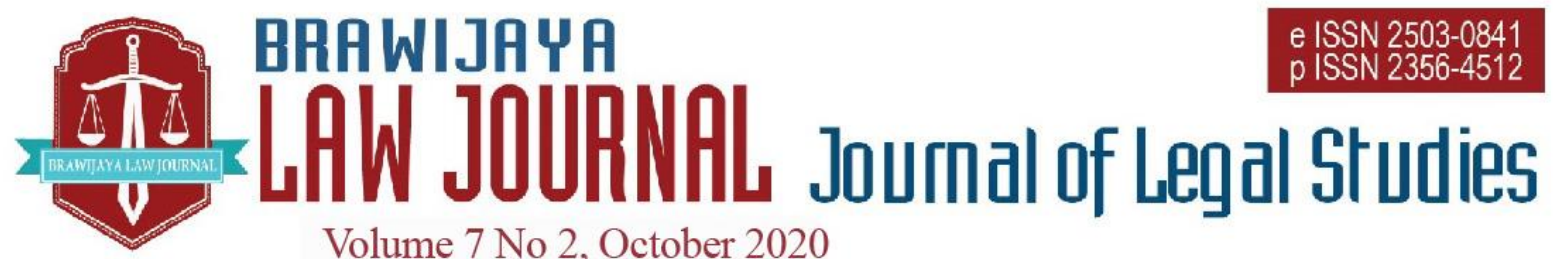

Volume 7 No 2, October 2020

Nationally Accredited No. 30/E/KPT/2018 Dated 24th October 2018

This work is licensed under a Creative Commons Attribution-NonCommercial 4.0 International License

\title{
Judicial Exposition of Gender Justice as a Constitutional Mandate: A Narrative from India
}

\author{
Shipra Gupta \\ Department of Laws, Panjab University, Chandigarh. \\ Email: shipragupta659@gmail.com
}

Submitted : 2020-07-27 | Accepted : 2020-09-27

\begin{abstract}
The catalytic role played by the Indian judiciary in providing visibility to the 'covert social prejudices' against females has succeeded in alleviating the condition of women in our patriarchal society. This paper strives to highlight the proactive role played by the judiciary in recent years, addressing women concerns in a different light, which were hitherto unconditionally accepted with complacence. Purposive approach adopted by the judiciary in interpreting existing laws, manifests adherence to the constitutional mandate of gender equality. Further, an attempt has been made to identify the areas where judicial action has fallen short in bringing about real justice to women. The research is primarily based on the normative method presenting qualitative analysis of the constitutional and legislative provisions and their judicial exposition. The paper concludes that judicial creativity needs the backing of social acceptability to bring about real social transformation towards the constitutional mandate of gender justice.
\end{abstract}

Keywords: constitution of india; gender justice; gender discrimination; judicial interpretation; social transformation; patriarchy.

\section{INTRODUCTION}

Justice connotes fair and equitable treatment of all individuals under law. It may be achieved through social justice or distributive justice that is reflected in equal share of benefits, burdens and responsibilities within society. However,

\footnotetext{
Sex is mostly related to biological features (chromosomes, sex organs, hormones and other physical features). See Anca Gheaus, 'Gender Justice' (2012) 6 (1, January) Journal of Ethics \& Social Philosophy 1, 3

<https://www.jesp.org/PDF/gender_justice_finali zed.pdf $>$ accessed on $23 / 07 / 2020$.
}

injustice is antithetical to the principles of justice; suffering because of one's sex ${ }^{1}$ amounts to gender injustice ${ }^{2}$. 'Gender' is understood to refer to the 'deeply entrenched social institutionalization of sexual difference'. ${ }^{3}$ Gender injustice is manifested in violence, discrimination, deprivation and 
exploitation against women in various spheres including social, economic, domestic, market and legal spheres. ${ }^{4}$

Gender justice is positively related to gender parity and gender equity ${ }^{5}$ and can be achieved by eliminating such inequalities that are generated and regenerated at every level ranging from family to state. It requires power and responsibility sharing between men and women at every level, i.e., domestic, workplace and community level- both nationally and internationally. ${ }^{6}$ To achieve gender justice, poverty and exclusion resulting from discrimination needs to be addressed by the mainstream institutions right from justice to economic policymaking. ${ }^{7}$ Gender equality paves way for gender justice and is crucial for the development of the country. Whereas, gender discrimination is an impediment in the overall development, poverty reduction and human progress.

Inherent gender bias within society operates at an unconscious level and permeates the social psyche in a subtle manner, thus perpetuating gender injustice. Such discreet influences make it arduous to control injustice in an up-front manner. ${ }^{8}$ At

<https://ir.lawnet.fordham.edu/cgi/viewcontent.cg i article $=3963 \&$ context $=$ flr $>$ accessed on 23 /07/2020.

4 Anca Gheaus, above n 2, 6

5 Gender parity is different from gender equality. 'Gender equality' conveys equal enjoyment of valued goods, resources, opportunities and rewards while 'gender equity' is understood as the process of being fair and just. It rather conveys equal distribution of resources based on gender specific needs. See, Binila Mathews, 'Gender Equity in Kerala: An Analysis of Constitutional Provisions and Civil Society Movement' (2019) 6(1) International Journal of Research and Analytical Reviews, 158, 158 <https://ijrar.com/upload_issue/ijrar_issue_20544 079.pdf > accessed on 30/10/20.

6 'Gender Justice', Oxfam $<$ https://policypractice.oxfamamerica.org/work/gender-justice/> accessed on 12/02/2019. an overt level, discriminatory socio-cultural practices with religious overtone, supported by archaic laws contribute in perpetuating subjugation of women in the patriarchal societies. Patriarchy has been defined as "a male-centered, male identified maledominated social system, as a source of continuing inequality between women and men". 9 Gender inequality has been gradually perpetuated by the patriarchal structures of society. ${ }^{10}$

It has been argued that the onus of making gender-just-society lies on individual action, much less on the legislation and social institutions. ${ }^{11}$ However, in recent times socially progressive legislations and judicial creativity have been instrumental in bringing about positive social transformation. This judicial creativity is reflected in the guidelines/directions issued by the Hon'ble Supreme Court of India from time to time for addressing gender bias. Furthermore, the purposive approach adopted by the judiciary for interpretation of existing laws, has tried to keep up with the spirit of constitutionalism.

7 'Gender Justice: Key to Achieving Millennium Development Goals', United Nations Development Fund for Women (UNIFEM), 3 <http://www.ungei.org/resources/files/MDGBrief -English.pdf > accessed on 20/09/2017.

8 See Virginia Valian 'Why So Slow? The Advancement of Women' (1999), Cambridge, MA: MIT Press, as referred in above (n 1) 7.

9 Mary Becker, 'Patriarchy and Inequality: Towards a Substantive Feminism' University of Chicago legal Forum (Vol.1999) Issue 1, Article 3, 21, 85 http://chicagounbound.uchicago.edu/uclf/vol1999 /iss 1/3 accessed on 20/10/20.

10 Shipra Kaushal, Gender Inequality: Illustrated Through a Legal Perspective on Female Foeticide, (Satyam Law International, 2014)

11 Anca Gheaus, 'Gender Justice' (2012) 6 (1, January) Journal of Ethics \& Social Philosophy above n 4, 20. 


\section{LEGAL MATERIAL AND METHODS}

The paper strives to highlight the proactive role played by the judiciary that has, to a great extent, contributed in presenting a novel perspective to women concerns, which were hitherto unconditionally accepted with complacence. The catalytic role played by judiciary has given visibility to socially embedded 'covert prejudices' pervading all spheres of a woman's life, from intimate family sphere to the public sphere. Attempt has been made to gauge the extent to which judiciary has succeeded in alleviating the condition of women in our patriarchal society. The paper further aims to identify the areas where judicial action has fallen short in bringing about real justice to women.

\section{RESULT AND DISCUSSIONS Gender Jurisprudence}

Gender jurisprudence, in recent times has evolved through a body of pro-women legislations and pro-active gender just judgements delivered by the higher judiciary, striking at the root of existing norms supporting gender bias in the society. The principle of equality of status and negation of gender bias permeates the entire structure of the Constitution of India. Basic constitutional principle of gender equality, entails judicial endeavour to interpret the statutes in consonance with the constitutional mandate

12 Velamuri Venkata Sivaprasad $v$ Kothuri Venkateswarlu (2000) 2 SCC 139, 148.

13 The Constitution of India, Articles 14, 15 (i), 16, 39 (a), 39 (d), 42, 51 (A)(e).

14 Medha Kotwal Lele v Union of India (2013) 1 SCC 297, 308.

15 Article 372, Constitution of India declares that "all laws in force in the pre-Constitution period shall remain in force unless lawfully altered, repealed, amended [or adapted] by a competent authority."

16 No reconciliation between the individual's fundamental rights and the discriminatory personal of equality based on sex. ${ }^{12}$ The Constitution is founded on the principle of equality and non-discrimination, and has struck a balance between individual rights and the State commitment to establish an egalitarian social order. Constitutional guarantee of equality in Part III is a positive assurance of 'gender justice'. Non-discrimination on the ground of 'sex' is a boon to further 'gender justice'. ${ }^{13}$ Our Constitution framers believed in fairness and justice for women. The States' commitment of gender parity and gender equality, non-discrimination and guarantee against sexual harassment to women is reflected in the Constitution. ${ }^{14}$ Despite Constitutional provisions and Fundamental Rights there remains a wide gap between $d e$ jure and de facto entitlements that are reflected in the regressive trends of social reality, primarily owing to pre-constitutional discriminatory 'personal laws' 15 that still retain stronghold ${ }^{16}$. To a great extent the reason for this disparity lies in India's secularism incorporating the maxim sarva dharma sambhava or "all religions are equal". However, this "religious pluralism" has spill over effect on the women's rights creating conflict between constitutional mandate of individual's equal protection and discriminatory personal laws; as the personal laws are judicially exempted from the requirements of Articles 13, 14, and 15 of the Indian Constitution. ${ }^{17}$

laws is possible until a "competent authority" reforms the law in conformity with Article 13 of the Constitution of India. Citing Tahir Mahmood, Personal Laws in Crises 6 (1986) in Cyra Akila Chaudhary, (Mis)Appropriated Liberty: Identity, Gender Justice and Muslim Personal Law Reform in India, (2008) 17 Colum. J. Gender \& L. 45, 65 $<$ https://ecollections.law.fiu.edu/faculty_publicati ons/94> accessed on 29/10/20.

17 Cyra Akila Chaudhary, '(Mis)Appropriated Liberty: Identity, Gender Justice and Muslim Personal Law Reform in India', (2008) 17 Colum. J. Gender \& L. $45,47 \quad \& \quad 67$. 
Article 14 of the Constitution embodies the principle of "non-discrimination". Articles $14,15^{18}$ and 16 form a group of provisions that confer right of equality on each individual citizen and must be read conjointly. ${ }^{19}$ These provisions specifically relate to gender equality which has been unequivocally recognised as a fundamental right. ${ }^{20}$ Our Constitution guarantees 'the trinity of rights' i.e., right to life, gender equality, equality of status and opportunity to all citizens of the country irrespective of 'sex'. Articles 13, 14, 15 and 16 of the Constitution of India and other related Articles prohibit discrimination on the ground of sex. ${ }^{21}$ Hence it is mandatory to render socio-economic justice to women so as to ensure their dignity of person, to bring them into the mainstream of the national life. ${ }^{22}$ The public policy and constitutional philosophy envisaged under Articles 38, 39, $46,15(1)$ and (3) and 14 is to accord social and economic democracy to women as assured in the Preamble of the Constitution. 23

'Life' in its expanded horizon encompasses all that makes a person's life meaningful. Therefore, integrating culture, heritage and tradition with 'dignity of person' becomes essential. The fulfilment of that heritage in full measure would

<https://ecollections.law.fiu.edu/faculty_publicati ons/94> accessed on 30/10/20.

18 C. B. Muthamma v Union of India AIR 1979 SC 1868. Rule 8 (2) of the Indian Foreign Service (Conduct and Discipline) Rules, 1961 that required unmarried woman to seek permission from the government before getting married and also could be asked to resign if her marriage was found to be interfering with her efficiency at work, was declared to be violative of Article 15 of the Constitution.

19 Vijay Lakshmi v Panjab University (2003) 8 SCC 440, 442-3.

20 Vishaka $v$ State of Rajasthan (1999) 6 SCC 241.

21 In Uttarakhand Mahila Kalyan Parishad and others v State of U.P. 1993 Supp (1) SCC 480, the preferential treatment to male teachers and male encompass the right to life. For a meaningful and purposeful 'life' every woman is entitled to elimination of obstacles and discrimination based on gender for human development. Women are entitled to enjoy economic, social, cultural and political rights without discrimination and on footing of equality. ${ }^{24}$ "Right to life" under Article 21 embodies several aspects of life. By expanding the scope of Article 21 the judiciary has played momentous role in furthering gender justice. ${ }^{25}$

The Directive Principle of State Policy provided under Article 39 (d) makes it obligatory on the state to provide equal pay for equal work and Article 51 (A) (e) imposes fundamental duty on every citizen to renounce practices derogatory to the dignity of women. By virtue of Constitution (Seventy-third) Amendment Act, 1992 and Constitution (Seventy-fourth) Amendment Act, 1992 one-third reservation for women in local governing bodies like Panchayats ${ }^{26}$ and in municipalities ${ }^{27}$ has been introduced as a significant step towards political empowerment of the women at the grassroot level.

Judiciary has meaningfully contributed to promote 'gender equality' 28 through purposive interpretation of statutory provisions in a number of judgements, ${ }^{29}$

employees was considered to be violative of Articles 14, 16(1) \& (2) of the Constitution of India that provide for parity in employment, where the nature of job is same.

22 Madhu Kishwar v State of Bihar (1996) 5 SCC 125, 148-9 ('Kishwar')

23 Ibid 152.

24 Ibid 148.

25 See Vishaka $v$ State of Rajasthan (1999) 6 SCC 241; Lata Singh v State of U.P. (2006) 5 SCC 475.

26 The Constitution of India, Articles 243 D (3) and 243 D (4).

27 The Constitution of India, Article $243 \mathrm{~T}$.

28 Joseph Shine $v$ Union of India W.P. (Criminal) 194 of 2017 ('Shine').

29 See Reema Aggarwal v Anupam Criminal Appeal No. 25 of 2004 wherein the Court favoured 
aligned with the spirit of the Constitution. In order to uphold the validity of constitutional mandate, various women specific provisions have been provided in the Indian Penal Code, 1860 to address mental and physical violence against women, such as- kidnapping and abduction for various purposes including prostitution, ${ }^{30}$ rape,${ }^{31}$ dowry death, ${ }^{32}$ mental and physical cruelty by husband and his relatives, ${ }^{33}$ molestation, ${ }^{34}$ acid attack, ${ }^{35}$ sexual harassment, 36 disrobing, 37 voyeurism, ${ }^{38}$ stalking, ${ }^{39}$ procuration of minor $\operatorname{girl}^{40}$ and importation of girls from foreign country 41 . Various women-centred legislations have been periodically enacted to address the socio-cultural discriminations faced by women in various spheres. ${ }^{42}$ There has been a long-drawn struggle for gender justice, both within the domestic sphere and outside. Despite strong resistance from social orthodoxy, the sustained efforts of several social reformers have succeeded in giving impetus to the cause of gender justice. Constitutional provisions, legislations, and the judgments of courts have cumulatively made significant contribution towards the cause of gender justice. ${ }^{43}$

purposive approach to the relationship of 'husband' and 'wife', while asserting that legalistic approach would encourage harassment to woman over demand of money. See also Koppisetti Subbharao v State of Andhra Pradesh Criminal Appeal No. 867 of 2009; and Richa Mishra v State of Chhattisgarh (2016) 4 SCC 179. The Court in this case allowed age relaxation to the appellant for her selection to the post of Deputy Superintendent of Police.

30 The Indian Penal Code 1860 s 363-73.

31 Ibid s 376.

32 Ibid s 304-B.

33 Ibid s 498-A.

34 Ibid s 509.

35 Ibid s 326 A, 326 B.

6 Ibid s $354 \mathrm{~A}$.

7 Ibid s 354 B.

38 Ibid s $354 \mathrm{C}$.

39 Ibid s 354 D.

Ibid s 366 A.

\section{Positive Discrimination-Towards Gender} Justice

Women in general face various kinds of gender disabilities and discriminations. The Constitution of India confers a unique status to women in terms of equality with men. In reality, however, they have yet to go a long way to achieve this constitutional status. ${ }^{44}$ Our Constitution makers were wary of the multi-faceted discriminations, deprivations and socio-economic handicaps faced by women in our society in every sphere like- social, cultural, economic, political etc. With an object to strengthen and improve the status of women and to remove the 'inequality' and wide 'disparity' in the society, Article 15 (3) as a "special provision" was inserted in the Constitution, to enable the State to improve women's participation in all activities under the supervision and control of the State in the form of either "affirmative action or reservation". ${ }^{45}$ Thus, the State is empowered to negate and neutralise all kinds of disadvantages faced by women in the social matrix, through 'positive-discrimination'. ${ }^{46}$

Article 14 ensures equality of law and prohibits invidious discrimination.

41 Ibid s 366 B.

42 The Hindu Succession (Amendment) Act 2005; the Maternity Benefit Act 1961 (as amended in 1995); The Dowry Prohibition Act 1961; The PreConception and Pre Natal Diagnostic Techniques (Prohibition of Sex-Selection) Act, 2001; The Prohibition of Child Marriage Act, 2006; The Protection of Women from Domestic Violence Act, 2006; The Sexual Harassment of Women at the Workplace (Prevention, Prohibition and Redressal) Act, 2013.

43 Justice Jitendra N. Bhatt, 'Gender Justice: Human Rights Perspective Triumph or Turmoil; Victor or Vanquished', (2006) 4, Supreme Court Cases (SCC) J-3, J-11('Gender Justice).

44 Richa Mishra v State of Chhattisgarh (2016) 4 SCC 179, 196.

45 Govt. of A.P. v P.B. Vijayakumar (1995) 4 SCC 520 ('Vijayakumar').

46 The Constitution of India, Article 15 (3). 
Arbitrariness and arbitrary exclusion are sworn enemies to equality. Equality before law is possible amongst the subjects who are equal. However, in case of evident 'inequality', positive measures are legitimately necessitated to bring them on par with each other, so as to be treated equally. While Article 14 is a general provision and has to be read subject to the other fundamental rights; Article 15 (3) relieves the State from the bondage of Articles 14 and 15(1) and charges it to make special provision to accord socio-economic equality to woman. ${ }^{47}$ Justice, equity and good conscience are integral part of equality under Article 14 of the Constitution which is the genus and Article 15 is its specie. ${ }^{48}$ Hence, any law that makes special provision for women or children under Article 15 (3) cannot be challenged as there is no inconsistency between Article 14 and 15 (3). Article 15 (3) permits the State to positively discriminate in favour of women by making special provision to ameliorate their condition leading to social, economic and political justice. Such positive provision accords parity to women, ${ }^{49}$ and thus positively protects such acts or actions that are more favourable to women. Such positive provision attains significance in a context where institutionalised discrimination appears to have disappeared only at the superficial level. The mind-set and the repressive attitude ingrained in the subconscious remain the same. Women are still subjected to all kinds of discrimination and prejudice. They are still regarded as feeble, dependent and subordinate to men, and nothing seems to have changed. ${ }^{50}$

47 Thota Sesharathamma $v$ Thota Manikyamma (1991) 4 SCC 312.

48 Kishwar (n 22) 159.

49 Ibid 145.

50 Charu Khurana v Union of India (2015) 1 SCC 192, 197 ('Khurana').
Therefore, besides the provisions for 'equality' and 'non-discrimination', Article 15 (3) was deliberately included to legitimise 'positive discrimination', i.e., to enable the State to enact special legislations/provisions in order to modify or abolish gender-based discrimination in the existing laws, regulations, customs and practices which constitute discrimination against women. It requires strict scrutiny test to be applied while assessing the proposed aims and implications of such legislations. The test to review such "protective discrimination statutes" on the ground of sex would entail a two-pronged scrutiny - a) the legislative interference should be justified in principle and b) the same should be proportionate in nature. Such legislations potentially serve as double edged swords. ${ }^{51}$

\section{Judicial Attitude towards Empowering Women}

In a recent case Richa Mishra v. State of Chhattisgarh, ${ }^{52}$ the Hon'ble Supreme Court identified inverse relation between economic development and poverty. The Court emphasised on a "bidirectional relationship" between economic development and women's empowerment. The Court opined that empowerment can accelerate development if women are given access to the constituents of development; particularly access to health, education, earning opportunities, rights, and political participation. The Court further affirmed that such "real empowerment" complimented with "economic empowerment" would enable them to enjoy the rights guaranteed to them. This will shift the focus from

51 D.D.Basu, Shorter Constitution of India, (LexisNexis Butterworths Wadhwa Nagpur, Fourteenth edn. 2009, Reprint 2014) 136. ('Basu')

52 Richa Mishra $v$ State of Chhattisgarh (2016) 4 SCC 179 ('Mishra'). 
"achieving better treatment" or "well-being of women" to "economic empowerment". 53 Empowerment is thus perceived in economic independence, self-reliance, and ability to participate in development activities. ${ }^{54}$ There is mutual interdependence and mutual reinforcement in the context of democracy, development and respect for human rights and fundamental freedoms. Equal participation of women in political, social, economic and cultural life is concomitant with national development, social and family stability and all round growth. ${ }^{55}$

\section{'Sex' as Reasonable Classification}

'Sex' has been accepted as a permissible classification with the realisation that it is not pragmatic to universalise or dogmatise equality of men and women in all situations. It has been recognised that the requirements of particular employment, the sensitivities of sex or the peculiarities of societal sectors or the handicaps of either sex, may compel selectivity. Unless, where the differentiation is demonstrable the rule of equality must govern. ${ }^{56}$ The substantive dimension of Article 15 (3) contemplates in its application, provision for special educational facilities, representation in local bodies and protection in places of work. The underlying inspiration behind Article 15 (3) would be hit at the root, if job opportunities could 'not' be created under special provisions. Making special provision for women in respect of employments or posts under the State has been considered to be an integral part of Article 15 (3). ${ }^{57}$

In Vijay Lakshmi v. Panjab University and others $^{58}$ the Supreme Court while interpreting Articles 14 to 16 relied on the established propositions of law holding sex to be a sound basis for classification. In the light of Article $15(3)$ the State is categorically empowered to make special provision for women and children. The Court approved of classification between male and female for certain posts. Such classification cannot be said to be arbitrary or unjustified. If separate colleges or schools for girls are justifiable, rules providing appointment of a lady Principal or teacher would also be justified as a precautionary, preventive and protective measure. ${ }^{59}$ Hence, rules empowering the authority to appoint only a lady Principal or a lady doctor or a lady teacher or a woman superintendent cannot be said to be violative of Article 14 or 16 of the Constitution. Reservation of fifty per cent of the posts in favour of female candidates was held to be justified and nonarbitrary in view of large number of young girls below the age of ten years studying in primary school. The Court considered it to be preferable for the young girls to be taught by women. ${ }^{60}$

Special provision for women to bring them on par with men in public employment needs to be acknowledged in the context of equality before law. 'Equality before law' is co-relative to the concept of rule of law for all round evaluation of healthy social order. ${ }^{61}$ The principle of equality does not mean that every law must have universal application for all persons who are not by nature, attainment or circumstances in the same position. Varying needs of different classes of persons often require separate treatment. ${ }^{62}$ A woman in our society has various disadvantages and should not be denied employment merely on the ground that she is a woman. Such a view would be violative of Article 14 of the Constitution. ${ }^{63}$ The twin Articles 15 and 16

59 Ibid 443.

60 Rajesh Kumar Gupta v State of U.P. (2005) 5 SCC $172,179$.

61 Dalmia Cement (Bharat) Ltd. v Union of India (1996) 10 SCC 104.

62 Basu, abobe n 51, 81 .

63 Air India v Nargesh Mirza AIR 1981 SC 1829, wherein the Hon'ble Court declared the provision

182 | Gupta - Judicial Exposition of Gender Justice as a Constitutional Mandate... 
prohibit a discriminatory treatment but at the same time do not prohibit preferential or special treatment of women, which is a positive measure in their favour. Giving meaningful exposition to the provision of 'positive discrimination' this Court in Air India Cabin Crew Assn. v. Yeshaswinee Merchant ${ }^{64}$ held that difference in the age of retirement of male and female members of the crew cannot be said to be violative of Articles 14, 15, 16 and 51-A (e) of the Constitution. The age of retirement for male crew members was fifty-eight years while the female crew members were allowed early retirement from flying duties at the age of fifty years. They also had an option to accept ground duties beyond fifty years up to the age of fifty-eight years. ${ }^{65}$

\section{Sexual Harassment at workplace}

'Sexual harassment' is the infringement of fundamental right of woman to gender equality under Article 14. It also violates her right to live with dignity under Article 21 of the Constitution that includes the right to safe environment free from sexual harassment. Sexual harassment depicts the unequal power relations between men and women. The women working in workplaces have a right to gender equality, to work with dignity and to a safe working environment. ${ }^{66}$ The meaning and content of fundamental rights in the Constitution is of sufficient amplitude to encompass all the facets of gender equality including prevention of sexual harassment or abuse. ${ }^{67}$ The Supreme

by which the air hostess would lose the job on pregnancy and would retire at the age of 35 years as unethical, abhorrent, arbitrary and unconstitutional.

64 (2003) 6 SCC 277.

65 Ibid $302-6$.

66 Vishakha v State of Rajasthan (1999) 6 SCC 241.

67 Ibid 251.

68 (1999) 1 SCC 759.
Court in Apparel Export Promotion Council v. A.K. Chopra, ${ }^{68}$ took a serious note of sexual harassment at the place of work. According to the Court each such incident resulted in violation of fundamental right to gender equality and right to life and liberty. The right of employment itself may not be a fundamental right but in terms of both Articles 14 and 16 of the Constitution of India, each person similarly situated has a fundamental right to be considered for same.

The gendered roles assigned to men and women in social and economic life are based on the conditioned perceptions about male and female sensuality which form the basis of commonly held beliefs or myths about sexual harassment. 69 Sexual harassment has been recognized as a kind of violence/gender discrimination against women by various international instruments. ${ }^{70}$ Sexual harassment of female at the place of work is incompatible with the dignity and honour of a female and needs to be eliminated. ${ }^{71}$

\section{Discrimination in Employment}

Patriarchal manifestations in the form of 'structures of control' and 'violence' are evident at various levels of nation, household, as well as community. Any threat to the sanctity of patriarchal state, household or community assumes significant projection in the form of 'security' and 'protection' justifying the male-centred power to take

69 'Year of Endeavour', (2002) National Commission Women, 142.

70 General Recommendation no. 19 adopted by the CEDAW Committee in 1992; The United Nations Declaration on Violence Against Women, 1993; The International Labour Organisation (ILO) Seminar, 1993, Manila.

71 Apparel Export Promotion Council v A. K. Chopra (1999) 1 SCC 759. 
charge. ${ }^{72}$ Discrimination in employment depicts the gender dynamics in the public sphere. Differential treatment is legitimised on the basis of social needs and biological difference. In a pathbreaking judgement, Secretary, Ministry of Defence v. Babita Puniya ${ }^{73}$ the Hon'ble Supreme Court removed the discriminatory restriction on women officers to serve only in staff appointments, and granted them permanent commission in ten streams of combat support arms and services, bringing them on par with male counterparts in the army. This decision marks a step towards realising the fundamental constitutional commitment. The Court rejected all arguments "based on sex stereotypes" on the assumptions about "socially ascribed gender roles" and "physiological limitations" on employability of women officers which discriminate against women. The Court underlined the need for change in mindsets to bring about true equality in the Army so as to enable women to enjoy benefits and status associated with seniority of rank.

In Neera Mathur v. LIC ${ }^{74}$, a female candidate was required to furnish information about her menstrual period, last date of menstruation, pregnancy and miscarriage. The Court declared that calling of such information are indeed embarrassing if not humiliating. The Court directed that the employer i.e. Life Insurance Corporation to delete such columns in the declaration. In Maya Devi v. State of Maharashtra ${ }^{75}$ where the requirement of husband's consent for

72 Navtej Purewal, Sex Selective Abortion, Neoliberal Patriarchy and Structural Violence in India, (accepted version) (2018) Issue 119, July Feminist

https://eprints.soas.ac.uk/25115/1/purewal-SSAfeminist-review-2018.pdf. The existing BJP Government has been condemned as a neoliberal state patriarchy, for actively promoting the strategic use of gender insecurity and violence for wife's application for public employment was struck down as an anachronistic obstacle to woman's equality and economic justice.

In Charu Khurana v. Union of India ${ }^{76}$, this Court considered the issue of gender discrimination in the matter of denial of membership of "Cine Costume Make-up Artists and Hair Dressers Association" in film industry. It was held that discrimination solely on the basis of sex violates basic constitutional rights and infracts constitutional values and norms. The sustenance of gender justice is the 'cultivated achievement of intrinsic human rights'. In the absence of equal opportunities at the threshold to enter into the sphere of profession, despite being eligible and qualified; equality in inconceivable. ${ }^{77}$

In Anuj Garg v. Hotel Assn. of India, ${ }^{78}$ the Hon'ble Supreme Court has preferred "empowerment of women" over "putting curbs on women's freedom" as a more tenable and socially wise approach. The Hon'ble Court suggested that it should reflect in law enforcement strategies of the State in terms of providing security and safety. The Court observed that no law in its ultimate effect should end up "perpetuating the oppression of women". The Hon'ble Court further emphasised on the importance of 'personal freedom' as a fundamental tenet beyond compromise, even in the name of expediency, otherwise than for a compelling State purpose. The Court recognised right to selfdetermination as an important offshoot of gender justice discourse. ${ }^{79}$ The Court

exercising its political power at all levels of society.

73 Civil Appeal Nos 1127-1128 of 2013 and with Civil Appeal No. 1210 of 2020.

74 (1992) 1 SCC 286

751986 (1) SCR 743

76 (2015) 1 SCC 192.

Ibid 210-14.

78 (2008) 3 SCC 1.

Ibid 13-19. 
proposed to shift the focus of the test to review protective discrimination under Article 15 (3) from its objects and aims to the consequences and effects of legislation. In this sense this case sets right 'acontextual view of sex discrimination' based on sex and 'unquestioned protectionism' of the state. ${ }^{80}$

While dealing with a sensitive issue of the discontinuance of prohibition of 'bar dancing' in certain establishments, the Supreme Court in State of Maharashtra $v$. Indian Hotel \& Restaurants Assn. ${ }^{81}$ noted that it would be better to 'treat the cause' than to 'blame the effect'. Prohibition on bar dancing would completely discontinue the livelihood of a large section of women, eking out an existence by dancing in bars, who would be exposed to other forms of exploitation. ${ }^{82}$ Disqualification to become a make-up artist by the Cine Costume Make-up Artists and Hair Dressers Association on ground of being a 'woman' has highlighted the prevalence of gender inequality in the film-industry, and has been regarded as offending the concept of gender justice. ${ }^{83}$

\section{Social Justice}

There are number of social justice legislations that give special protection and benefits to vulnerable groups in the society. The courts have to adopt different approaches in "social justice adjudication", which is also known as "social context adjudication". It is believed that mere

${ }^{80}$ Shreya Atrey, 'Through the Looking Glass of Intersectionality: Making Sense of Indian Discrimination Jurisprudence under Article 15' The Equal Rights Review, (2016) Vol. Sixteen at

https://www.equalrightstrust.org/ertdocumentban $\mathrm{k} /$ Through\%20the\%20Looking\%20Glass\%20of\% 20Intersectionality $\% 20$ Making $\% 20$ Sense $\% 20$ of $\%$ 20Indian\%20Discrimination\%20Jurisprudence $\% 2$ Ounder\%20Article\%2015.pdf174

81 State of Maharashtra v Indian Hotel \& Restaurants Assn. (2013) 8 SCC 519. "adversarial approach" may not be very appropriate. ${ }^{84}$ The courts have advocated purposive interpretation of the statutory provisions, in cases where the purpose is to achieve "social justice" in line with the constitutional vision, enshrined in the Preamble of the Constitution of India. While giving interpretation to a particular provision, the court is supposed to bridge the gap between law and society so as to advance the cause of social justice. ${ }^{85}$ It has been observed that while interpreting statutory provisions, in a socially relevant manner, constitutional empathy for the weaker sections like women and children must be reflected in it. ${ }^{86}$

With an expanded horizon in viewing gender justice, the Hon'ble Supreme Court took a very different perspective towards the offence of 'adultery' in a very recent pathbreaking judgement in Joseph Shine. ${ }^{87}$ The Hon'ble Court declared Section 497 of the Indian Penal Code, 1860 to be unconstitutional being violative of Articles 14, 15 and 21, as it considers women subordinate to men in as much in laying down that "when there is connivance or consent of the man, there is no offence". This treats wife as the "property" of husband and is a reflection of social dominance as the basis of such a penal provision. The Court also refuted the basis of its legitimacy in protecting or preserving the sanctity of marriage, because having sexual intercourse

82 Ibid 591.

83 Khurana (n 50) 197.

84 Badshah v Urmila Badshah Godse (2014) 1 SCC 188, 196; see also Richa Mishra v State of Chhattisgarh (2016) 4 SCC 179.

85 Badshah v Urmila Badshah Godse (2014) 1 SCC 188, 196-9.

86 Capt. Ramesh Chander Kaushal v Veena Kaushal (1978) 4 SCC 70, 74.

87 Shine (n 28). 
with a widow or an unmarried woman would not entail same penal consequences as having sexual relation with a married woman. Rather this provision affirms the proprietary right of the husband over his wife. The Court also found it to be violative of Article 14 and Article 15 (1) as it discriminates on the ground of 'sex' ${ }^{88}$ In another recent case the Hon'ble Supreme Court struck down the practice of 'triple talaq' to be arbitrary and violative of Article 14 as it allows marital ties to be broken capriciously and whimsically by a Muslim husband. ${ }^{89}$ However, the Court seemed more concerned with 'preservation of marriage' than with 'women's rights', therefore the judgement has been criticised for missing out on engaging with the intersectionality of gender and religious identity. ${ }^{90}$ In yet another recent judgement Independent Thought, 91 the Hon'ble Supreme Court read down Exception 2 to Section 375 of the Indian Penal Code, 1860 and declared sexual intercourse with a wife below eighteen years of age to be rape. However, the Court did not deal with the issue of marital rape otherwise.

In a recent historical judgement Indian Young Lawyers Association v. State of Kerala,${ }^{92}$ the five judge Constitution Bench with 4:1 majority struck down the exclusionary practice, backed by a rule, that

88 Overruling Sowmithri Vishnu v Union of India (1985) Supp SCC 137; V. Revathi v Union of India (1988)2 SCC 72.

89 Shayara Bano v Union of India Writ Petition (C) No. 118 of 2016 , <https://www.sci.gov.in/pdf/LU/Supreme\%20Co urt $\% 20$ of $\% 20$ India\%20Judgment $\% 20 \mathrm{WP}(\mathrm{C}) \% 20$ No.118\%20of\%202016\%20Triple\%20Talaq.pdf> accessed on 22/02/2019 ('Bano').

90 Tanza Herklotz, 'Law, Religion and gender equality: literature on the Indian personal law system from a woman's rights perspective' (2017) Vol. 1, Issue 3 Indian Law Review $<$ https://www.tandfonline.com/doi/full/10.1080/2 4730580.2018.1453750> accessed on 30/10/2020

91 Independent Thought v. Union of India Writ Petition Civil No. 382 of 2013 , did not allow women in the 10-50 years age group to enter Kerala's Sabarimala temple of Lord Ayyappa. The rule was declared to be violative of the right of Hindu women to practise their religious beliefs which, in effect negates their fundamental right of religion under Article 25(1). ${ }^{93}$ The Court did not find favour with 'patriarchy in religion' that interferes with element of pure devotion and the freedom to practise and profess one's religion. ${ }^{94}$

In Anil Kumar Mahsi v. Union of India,${ }^{95}$ constitutionality of Section 10 of the Indian Divorce Act was challenged by an aggrieved husband to be discriminatory against husband. It was claimed to be violative of Article 14, as it allows two grounds to the wife and not to the husband for seeking dissolution of the marriage. The Court did not find any substance in the challenge. The Court however, took note of the muscularly weaker physique of the woman, her general vulnerable physical and social condition and her defensive and nonaggressive nature and role particularly in this country. ${ }^{96}$ In view of the purpose of Section 125 Cr.P.C. the Supreme Court in Savitaben Somabhai Bhatiya $v$. State of Gujarat, ${ }^{97}$ pointed that it is enacted for social justice, especially to protect women, children, old and infirm poor parents, and thus falls within

<https://www.sci.gov.in/supremecourt/2013/1779 0/17790_2013_Judgement_11-Oct-2017.pdf> accessed on 23/02/2019 ('Independent Thought').

92 Writ Petition (Civil) No. 373 of 2006, <https://www.supremecourtofindia.nic.in/suprem ecourt/2006/18956/18956_2006_Judgement_28Sep-2018.pdf $>$ accessed on 23/ 02/2019. Rule 3(b) of the Kerala Hindu Places of Public Worship (Authorisation of Entry) Rules, 1965 was struck down by the Court ('Young Lawyers').

93 Ibid

94 Ibid 3

95 (1994) 5 SCC 704.

96 Ibid 708.

97 (2005) 3 SCC 636.

186 | Gupta - Judicial Exposition of Gender Justice as a Constitutional Mandate... 
the Constitutional sweep of Article 15(3) reinforced by Article 39 of the Constitution. Its provisions are applicable and enforceable irrespective of the personal law by which the persons concerned are governed. ${ }^{98}$

In Prakash v. Phulavati 99 it was pointed out that in spite of guarantee of the Constitution, Muslim women are subjected to discrimination as there is no safeguard against arbitrary divorce and second marriage by her husband during currency of the first marriage, resulting in denial of dignity and security to her. In Danial Latifi v. Union of India ${ }^{100}$ the Constitution Bench held that Article 21 included the right to live with dignity which supports the plea that a Muslim woman could invoke fundamental rights in such matters. In Githa Hariharan v. Reserve Bank of India ${ }^{101}$ this Court while construing Section 6(a) of the Hindu Minority and Guardianship Act, 1956 and Section 19(b) of the Guardians and Wards Act, 1890 considered the predominant object of the legislation in conjunction with the constitutional guarantee of gender equality and recognised equal status of mother as the natural guardian like father even during his life. ${ }^{102}$

\section{Violence against Women and Article 21}

Article 21 of the Constitution of India reinforces "right to life". Assault on a woman offends her dignity. There is a phenomenal rise in crime against women. Majority of women specific violent crimes are associated with her sexual vulnerability. The protection

98 Ibid 640.

99 (2016) 2 SCC 36.

100 (2001) 7 SCC 740; see also Ahmedabad Women Action Group (AWAG) v Union of India (1997) 3 SCC 573.

101 (1999) 2 SCC 228.

102 Ibid 246.

103 Vajresh Venkatray Anvekar v State of Karnataka (2013) 3 SCC 462, 471. granted to women by the Constitution of India and other laws can be meaningful only if those who are entrusted with the job of doing justice are sensitised towards women's problems. ${ }^{103}$ The most humiliating aspect of crime against a woman is that her status in the hierarchical structure of society also comes in the way of securing justice for her. Thus, her social status compounds her gender injustice. ${ }^{104}$ Rape is the worst form of intrusion of her privacy, both physical and mental and is a human rights violation and violation of right to life enshrined in Article 21 of the Constitution of India. The offence of rape affects the dignity of a woman and covers right to dignity and reinforces protection against rape and other sexual infractions. ${ }^{105}$ In view of International Covenant on Economic, Social and Cultural Rights; United Nations Declaration of Basic Principals of Justice for Victims of Crime And Abuse of Power 1985, rape survivors are entitled to legal recourse that does not retraumatise them or violate their physical or mental integrity and dignity. They are also entitled to medical procedures conducted in a manner that respects to their right to consent. There should be no arbitrary or unlawful interference with her privacy. Two finger test and its interpretation violates the right of rape survivors to privacy, physical and mental integrity and dignity. ${ }^{106}$ With a view to do gender justice, the Hon'ble Supreme Court has extended the protection of "right to life" even to a foreigner rape victim, thus laying down that they also have the right to live, so

104 Bhatt, 'Gender Justice', (n 43) J-11.

105 State of M.P. v Munna Choubey (2005) 2 SCC 710; see also Lillu v State of Haryana, (2013) 14 SCC 643 at 648.

106 Lillu $v$ State of Haryana 2013 (2) RCR (Criminal) 679, 682; see also State of Punjab v Ramdev Singh (2004 (1) RCR (Criminal) 345. 
long as they are here, with human dignity. ${ }^{107}$ Persistent 'sexual and gender-based violence' has serious implications on the communities in general and the victims and their families in specific. Such violence adversely affects the development progress as its spill-over effect. ${ }^{108}$

The State is duty-bound to protect the fundamental rights of its citizens; and an inherent aspect of Article 21 of the Constitution would be the freedom of choice in marriage. Gang rape ordered by the community Panchayat for having relationship with a man from a different community is an offence resultant of the State's incapacity or inability to protect the fundamental rights of its citizens. ${ }^{109}$ In Lata Singh v. State of U.P. ${ }^{110}$ considering instances of harassment, violence and threats against young men and women who marry outside their religion or caste to be an infringement of right to life, freedom of conscience and expression, the Court expressed its concern towards such instances sometimes leading to "honour killings".

\section{GENDER JUSTICE- DE JURE AND DE FACTO}

The constitutional commitment enforced through legislative measures coupled with pro-active judicial intervention has been instrumental in evolving a more liberal, equitable and fair paradigm of gender justice. "Equality" and "discrimination" are antithetical to each other, still both have been reconciled through "positive discrimination" in favour of women to bring about equality between men and women. The feminist

107 Chairman, Railway Board $v$ Chandrima Das (2000) 2 SCC 465.

108 'Gender Justice', United Nations Development Programme,

<http://www.undp.org/content/undp/en/home/de mocratic-governance-and-peacebuilding/rule-of- jurisprudence in terms of Part III of the Constitution has, to a great extent succeeded in transforming the de jure entitlements into de facto entitlements towards achieving gender justice in real terms; thus making law a "living reality".

The need of 'gender justice' is felt and understood in the context of 'gender injustice'. This 'injustice' is associated with 'discrimination', manifested in multiple deprivations faced by women from womb to tomb. The nature of deprivations and discriminations are relative and pervade every stage and every aspect of life, i.e., social, economic, political, religious etc. A pragmatic step towards achieving gender justice is to have 'gender just laws' that touch upon every aspect of female's life. Purposive approach towards interpreting these laws is a sine qua non for an equitable world.

In words of John Stuart Mill:

The legal subordination of one sex to another - is wrong in itself, and now one of the chief hindrances to human improvement; and that it ought to be replaced by a system of perfect equality, admitting no power and privilege on the one side, nor disability on the other. ${ }^{11}$

However, such 'perfect equality' still appears to be a far cry as the entire globe is afflicted with gender bias. The Gender Social Norms Index released by United Nations Development Fund has reported that almost ninety per cent men and women across the world are biased against women indicating the latent obstacles in achieving equality

\footnotetext{
law--justice--security-and-human-rights/genderjustice.html> accessed on 12/02/2019

109 Gang-Rape Ordered by Village Kangaroo Court in W.B., In re (2014) $4 \mathrm{SCC} 786,796$.

110 (2006) 5 SCC 475

111 Shine (n 28) quoting John Stuart Mill.
} 
'despite decades of progress closing the equality gap between men and women'. ${ }^{112}$

There is sufficient evidence of the positive role played by the judiciary in recent years in addressing those issues, which were hitherto, seen with 'gendered' perspective and hence, subversive to womanhood. Some of the most important developments in law in the recent times have changed the social matrix. Most of the developments are concerning very basic aspects of life, i.e. right to life, right to safe environment, both inside and outside home, right of mother as the legal guardian of child etc. For example, the genesis of law for the prevention of sexual harassment is owed to the judicial creativity in Vishakha. ${ }^{113}$ While Delhi Rape Case $^{114}$ galvanised the State to come up with the Criminal Law (Amendment) Act, 2013 adding a range of sexual offences against women and enhancing punishments for deterrence. Directions have been periodically issued by the Hon'ble Supreme Court to enable proper implementation and follow up of the Pre-conception \& Pre-natal Diagnostic Techniques (Prohibition of Sex Selection) Act, 1994 to curb female foeticide. ${ }^{115}$ 'Mother' was recognised as a natural guardian during lifetime of father in

112 '2020 Human Development Perspectives, Tackling Social Norms: a game changer for gender inequalities' United Nations Development Programme (UNDP), $<$ http://hdr.undp.org/en/gsni $>$ accessed on 22/07/2020.

113 Vishaka $v$ State of Rajasthan (1999) 6 SCC 241.

${ }^{114}$ Mukesh v NCT of Delhi Cr. Appeal Nos. 607-608 of 2017, arising out of S.L.P. (Cr.) Nos. 3119-3120 of 2014 available at <https://www.sci.gov.in/jonew/judis/44879.pdf> accessed on 24.02.2019.

115 Centre for Enquiry into Health and Allied Themes $v$ Union of India, (2001) 5 SCC 577; Voluntary Health Association $v$ State of Punjab (2013) 4 SCC 1.

116 Gita Hariharan v Reserve Bank of India (1999) 2 SCC 228.

117 ABC v State (NCT of Delhi) (2015) 10 SCC 1.
Gita Hariharan ${ }^{116}$, and unwed mother was recognised as the sole legal guardian of the child even without father's consent. ${ }^{117}$ The Hon'ble Supreme Court directed formulation of scheme for awarding compensation to the rape victims; ${ }^{118}$ struck down the rules prohibiting women from entering Sabrimala temple ${ }^{119}$; declared sexual intercourse with a minor wife to be punishable as rape ${ }^{120}$, and declared adultery ${ }^{121}$ and practice of triple talaq ${ }^{122}$ to be unconstitutional. Such progressive judgements have received perceptible general public support, and have certainly prompted the populace to accept and welcome the positive changes.

However, there are areas that still remain unchanged despite judicial initiative. For instance the Court in Seema v. Ashwani Kumar $^{123}$ directed to make registration of marriage compulsory, but there is no headway in this regard so far. In rape cases, resulting in pregnancy, the courts are still adhering to pedantic approach to the disadvantage of victim, disallowing termination beyond twenty weeks, protracting the suffering of the victim. ${ }^{124}$ Declaring offence of adultery as unconstitutional still leaves an open question that requires conscientious deliberation -

118 Delhi Domestic Working Women's Forum v Union of India (1995) 1 SCC 14.

119 'Young Lawyers' (n 82).

120 'Independent Thought' (n 81).

121 'Shine' (n 28).

122 'Bano' (n 89).

123 (2006) 2 SCC 578, wherein the Court had directed to make registration of marriage compulsory that would help in curbing child marriage and fake marriages.

${ }^{124}$ It is only in a few judgements the Supreme Court has allowed termination of pregnancy on ground of risk to physical health of the mother, e.g., in $X v$ Union of India (2016) CWP 593 (IND); Chandrakant Jayantilal Suthar $v$ State of Gujarat, (2015) 8 SCC.

${ }^{124}$ State v Shanker CNR No.: CHCH010097132017, Sessions Case No. 169 of 10.10.2017 Date of Decision: 31.10.2017. 
whether it is going to improve the condition of women where the husbands are in relationships outside marriage? These delicate areas affecting domestic and personal sphere, where the issues are most intimate, sensitive and crucial to the autonomy of women, have much scope for judicial ingenuity.

\section{CONCLUSION AND SUGGESTIONS}

There is sufficient account of injustice suffered by women in the name of gender that has been periodically addressed by the judiciary in India. The negative association of 'gender bias' with female sex can be evidenced right before birth where the 'being' of a girl is unwelcome primarily due to 'social' factors like low social status, practice of dowry, violence against women etc. The judiciary has pro-actively dealt with pre-conception and pre-natal sex selection with iron hand to ensure the implementation of law prohibiting the same. The judiciary in India has attempted to assail the patriarchal structure of society that has practically seeped into the lives of women in different forms at all levels- from private and most intimate, to the public sphere. Catena of judicial pronouncements have addressed the issues relating to marriage, property rights, guardianship, etc governed by the discriminatory personal laws in the personal sphere and matters relating to employment, violence and social entitlements, in the public sphere. Holding the provision of adultery as unconstitutional, for derogating woman as the property of man, came as a blow to the patriarchal mindset, that asserts the primacy and superiority of the male in the institution of marriage. Reading down the exception to the provision of rape of wife below eighteen years of age has been another important stride in dismantling the non-porous wall of marriage as an institution that promotes the dominance of male.

From merely being the sentinel of the constitutional principles and values, the Indian judiciary has evolved as the protector of the rights of women as 'individuals'. Judiciary has expanded the scope of fundamental rights pertaining to equality, dignified life, economic justice, political representation and physical protection that has gone a long way in changing the lives of women. Lately the Hon'ble Supreme Court has adopted the purposive interpretation of statutory provisions, side-lining the pedantic legalistic approach in dispensing with the justice to the women. The inequalities caused by gender injustice(s), repression and subordination of women have been recognised by the judiciary as major factors hampering the economic development of the nation. Such positive and progressive attitude of the judiciary has paved the way for women to 'equality' in employment; be it addressing sexual harassment at the workplace or otherwise granting equal treatment in different kinds of employments such like bar dancing, makeup artist in film industry or even the armed forces.

The judiciary, through its judgements has manifested a certain level of social wisdom that has helped in evolving a 'gender sensitive' jurisprudence. This has been made possible due to the pragmatic approach adopted by the judiciary in the enforcement of "intrinsic human rights" and at the same time being mindful of the practical reality of women in our patriarchal social set up. Judiciary's function is to create a bridge between law and society in order to advance the cause of social justice. In recent years the judiciary has showcased the combination of constitutional empathy and social relevance in interpreting the statutory provisions. 
In the end it may be concluded that law is certainly not the panacea for all ills, but it does contribute in taking affirmative action towards achieving gender justice. Progressive laws and their purposive interpretation go hand in hand in introducing 'positive conditioning' and 'positive perspective' to look at gender issues in a 'different' way, that might not be palatable to the hardcore patriarchs. Nonetheless, on various occasions our judiciary has challenged the patriarchal norms and archaic laws that have been responsible, over the ages, for the subjugation of women. The judicial exposition of laws has kept the spirit of Constitution alive by striking down the arbitrary rules that reinforce gender prejudices inherent in the society. This has given a fresh and more progressive outlook to gender justice that would gradually lead to equality between men and women in all possible ways.

It is hoped that constitutional commitment advanced by "legal creativity" will gradually succeed in attaining "perfect equality" to a great extent. The blend of judicial creativity and social acceptability of the new perspectives presented by the judiciary would be a sine qua non for the real transformation. In order to accelerate the contributions of judicial endeavours in this regard, it is important to address gender issues from the perspective of economic empowerment through policy making, gender-budgeting and empowering women at the grass-root level.

\section{REFERENCES}

\section{Book}

Basu, D.D, Shorter Constitution of India, (LexisNexis Butterworths Wadhwa Nagpur, Fourteenth edn. 2009, Reprint 2014)
Kaushal, Shipra, Gender Inequality: Illustrated Through a Legal Perspective on Female Foeticide, (Satyam Law International, 2014)

\section{Journals}

Atrey, Shreya 'Through the Looking Glass of Intersectionality: Making Sense of Indian Discrimination Jurisprudence under Article 15' The Equal Rights Review (2016) Vol. Sixteen

https://www.equalrightstrust.org/ertdocume ntbank/Through\%20the\%20Looking\% 20Glass $\% 20$ of $\% 20$ Intersectionality $\% 2$ 0Making\%20Sense $\% 20$ of\%20Indian $\%$ 20Discrimination\%20Jurisprudence $\% 20$ under\%20Article\%2015.pdf

Becker, Mary, 'Patriarchy and Inequality: Towards a Substantive Feminism' University of Chicago legal Forum (Vol.1999) Issue 1, Article 3 http://chicagounbound.uchicago.edu/u clf/vol1999/iss1/3

Bhatt, Jitendra N., 'Gender Justice: Human Rights Perspective Triumph or Turmoil: Victor or Vanquished', (2006) 4, Supreme Court Cases (SCC) J-3 Choudhury, Cyra Akila, '(Mis)Appropriated Liberty: Identity, Gender Justice and Muslim Personal Law Reform in India' (2008) 17 Colum. J. Gender \& L. 45

EPW engage (Online), Personal Laws versus Gender Justice: Will a Uniform Code Solve the Problem Economic \& Political weekly https://www.epw.in/node/152995/pdf

Gheaus, Anca 'Gender Justice' (2012) 6, (1, January) Journal of Ethics \& Social Philosophy

https://www.jesp.org/PDF/gender_justi ce_finalized.pdf 1

Herklotz, Tanza, 'Law, Religion and gender equality: literature on the Indian 
personal law system from a woman's rights perspective' (2017) Vol. 1, Issue 3 Indian Law Review https://www.tandfonline.com/doi/full/ 10.1080/24730580.2018.1453750

Mathews, Binila, 'Gender Equity in Kerala: An Analysis of Constitutional Provisions and Civil Society Movement' (2019) Volume 6, Issue 1 International Journal of Research and Analytical Reviews

Okin, Susan Moller, 'Gender, Justice and Gender: An Unfinished Debate', (2004) 72 Fordham L. Rev. 1537 https://ir.lawnet.fordham.edu/cgi/view content .cgi article $=3963 \&$ context $=$ flr

Purewal, Navtej, Sex Selective Abortion, Neoliberal Patriarchy and Structural Violence in India, (2018) Issue 119, July, Feminist Review

\section{Reports}

'2020 Human Development Perspectives, Tackling Social Norms: a game changer for gender inequalities' United Nations Development Programme (UNDP), http://hdr.undp.org/en/gsni

'Gender Justice: Key to Achieving Millennium Development Goals', United Nations Development Fund for Women (UNIFEM), 3

'Gender Justice: Key to Achieving Millennium Development Goals', United Nations Development Fund for Women (UNIFEM), 3 http://www.ungei.org/resources/files/ MDGBrief-English.pdf

'Gender Justice', Oxfam https://policypractice.oxfamamerica.org/work/gende r-justice/

'Gender Justice', United Nations Development Programme, http://www.undp.org/content/undp/en/ home/democratic-governance-and- peacebuilding/rule-of-law--justice-security-and-human-rights/genderjustice.html

'Year of Endeavour', (2002) National Commission Women, 142.

The International Labour Organisation (ILO) Seminar, 1993, Manila.

The United Nations Declaration on Violence against Women, 1993

\section{Legislations}

The Constitution of India

The Dowry Prohibition Act 1961

The Hindu Succession (Amendment) Act 2005

The Indian Foreign Service (Conduct and Discipline) Rules 1961

The Indian Penal Code 1860

The Kerala Hindu Places of Public Worship (Authorisation of Entry) Rules 1965

The Maternity Benefit Act 1961 (as amended in 1995)

The Pre-Conception and Pre Natal Diagnostic Techniques (Prohibition of Sex-Selection) Act 2001

The Prohibition of Child Marriage Act 2006

The Protection of Women from Domestic Violence Act 2006.

The Sexual Harassment of Women at the Workplace (Prevention, Prohibition and Redressal) Act 2013.

\section{List of cases}

$A B C$ v. State (NCT of Delhi) (2015) 10 SCC 1.

Ahmedabad Women Action Group (AWAG) v. Union of India (1997) 3 SCC 573.

Air India v. Nargesh Mirza AIR 1981 SC 1829.

Anil Kumar Mahsi v. Union of India (1994) 5 SCC 704.

Apparel Export Promotion Council v. A. K. Chopra (1999) 1 SCC 759. 
Badshah v. Urmila Badshah Godse (2014) 1 SCC 188.

C.B. Muthamma v. Union of India (1979) 4 SCC 260.

Capt. Ramesh Chander Kaushal v. Veena Kaushal (1978) 4 SCC 70.

Centre for Enquiry into Health and Allied

Themes $v$ Union of India (2001) 5

SCC 577.

Chairman, Railway Board v Chandrima Das (2000) 2 SCC 465.

Chandrakant Jayantilal Suthar $v$ State of Gujarat (2015) 8 SCC.

Charu Khurana $v$ Union of India (2015) 1 SCC 192.

Dalmia Cement (Bharat) Ltd. $v$ Union of India (1996) 10 SCC 104.

Danial Latifi v Union of India (2001) 7 SCC 740.

Delhi Domestic Working Women's Forum v

Union of India (1995) 1 SCC 14.

Gita Hariharan v Reserve Bank of India (1999) 2 SCC 228.

Govt. of A.P. v P.B. Vijayakumar (1995) 4 SCC 520.

Re Gang-Rape Ordered by Village Kangaroo Court in W.B. (2014) 4 SCC 786.

Independent Thought $v$ Union of India Writ Petition Civil No. 382 of 2013

Indian Young Lawyers Association v State of Kerala Writ Petition (Civil) No. 373 of 2006

Joseph Shine $v$ Union of India W.P. (Criminal) 194 of 2017.

Koppisetti Subbharao $v$ State of Andhra Pradesh Criminal Appeal No. 867 of 2009

Lata Singh v State of U.P. (2006) 5 SCC 475. Lillu $v$ State of Haryana, (2013) 14 SCC 643.

Madhu Kishwar v State of Bihar (1996) 5 SCC 125.

Medha Kotwal Lele v Union of India (2013) 1 SCC 297.
Mukesh v NCT of Delhi Cr. Appeal Nos. 607-608 of 2017 arising out of S.L.P. (Cr.) Nos. 3119-3120 of 2014.

Neera Mathur v LIC (1992) 1 SCC 286.

Prakash v Phulavati (2016) 2 SCC 36.

Rajesh Kumar Gupta v State of U.P. (2005) 5 SCC 172.

Reema Aggarwal v Anupam \& ors Criminal Appeal No. 25 of 2004.

Richa Mishra v State of Chhattisgarh (2016) 4 SCC 179.

Savitaben Somabhai Bhatiya $v$ State of Gujarat (2005) 3 SCC 636.

Secretary, Ministry of Defence $v$ Babita Puniya Civil Appeal Nos 1127-1128 of 2013 and with Civil Appeal No. 1210 of 2020.

Seema v Ashwani Kumar (2006) 2 SCC 578.

Shayara Bano v Union of India Writ Petition (C) No. 118 of 2016.

Sowmithri Vishnu v Union of India (1985) Supp SCC 137.

State of M.P. v Munna Choubey (2005) 2 SCC 710.

State of Maharashtra $v$ Indian Hotel \& Restaurants Assn. (2013) 8 SCC 519.

State of Punjab v Ramdev Singh (2004 (1) RCR (Criminal) 345.

State v. Shanker CNR No.: CHCH010097132017 Sessions Case No. 169 of 10.10.2017.

Thota Sesharathamma v Thota Manikyamma (1991) 4 SCC 312.

Uttarakhand Mahila Kalyan Parishad and others v State of U.P. 1993 Supp (1) SCC 480.

V. Revathi v Union of India (1988)2 SCC 72.

Vajresh Venkatray Anvekar $v$ State of Karnataka (2013) 3 SCC 462.

Valsamma Paul v Cochin University (1996) 3 SCC 545.

Velamuri Venkata Sivaprasad v Kothuri Venkateswarlu (2000) 2 SCC 139. 
Vijay Lakshmi v Panjab University (2003) 8

SCC 440.

Vishaka v State of Rajasthan (1999) 6 SCC

241.

Voluntary Health Association v State of

Punjab (2013) 4 SCC 1.

$X v$ Union of India (2016) CWP 593 (IND) 